\title{
DESIGN OF VENTURIMETER DIAMETER FOR THE PRACTICAL APPLICATION IN AGRICULTURE SECTOR
}

\author{
P. H. J. Venkatesh \\ Department of Mechanical Engineering, \\ Vignan's Institute of Information Technology (A) \\ Visakhapatnam, A.P., India
}

\begin{abstract}
The importance of Agriculture is increased and the crop productivity with high quality and quantity are produced. In order to maintain the proper quality and the growth of the crop the rich nutrients are required and these are supplied to the crop with the fertilizers. The fertilizers are available in the form of powder based and liquid based. It is not possible for the farmers to supply the fertilizer in time with the required quantity. In this paper to minimize the effort and the required quantity of fertilizer with water is made available to each plant. A case study of Mango Plantation was choosen to design a venturimeter such that uniform rate of flow of the liquid fertilizer to be supplied to each Mango Plant based on the requirement in this process the required diameter of the venturimeter throat is calculated.
\end{abstract}

Keywords-Venturimeter, Quantity Throat, Liquid Fertilizer

\section{INTRODUCTION}

A venturimeter consists of convergent, Divergent and throat with a circular cross section[6].In venturimeter the fluid flows from the it convergent section with high acceleration and decelerates at the divergent section, which results a static pressure drop and recovery of the pressure happens in the direction of the flow.Then the pressure difference is measured at upstream of the convergent section and other at the throat, the volumetric flow rate can be determined.The venturimeter is works on the principle of Bernoulli's equation[6].The Bernoulli's statement states that in a steady, ideal flow of an incompressible fluid, the total energy at any point of the fluid will be constant.

The total energies are sum of pressure energy, kinetic energy and datum energy. Mathematical equation can be written as,

$$
\frac{p_{1}}{\rho g}+\frac{v_{1}^{2}}{2 g}+z_{1}=\frac{p_{2}}{\rho g}+\frac{v_{2}^{2}}{2 g}+z_{2}
$$

\author{
Vivek Viswanadha \\ Department of Electrical and Electronics Engineering \\ Vignan's Institute of Information Technology (A) \\ Visakhapatnam, A.P., India
}

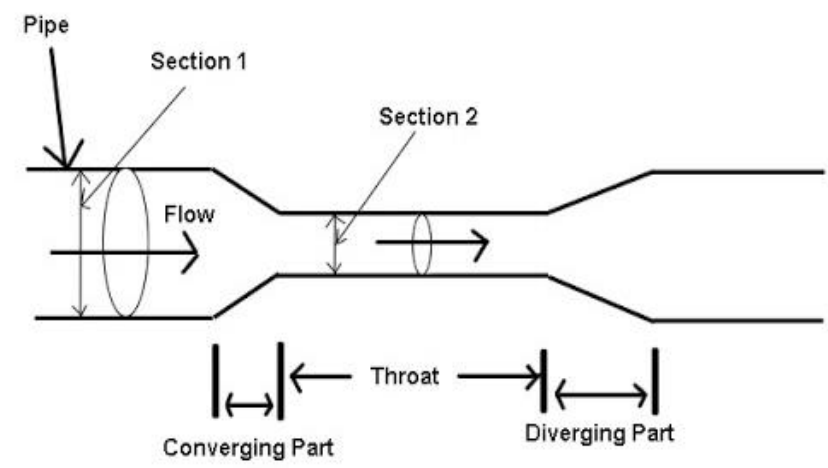

Venturimeter

Figure.1. Venturimeter

\section{FLOW METER IN AGRICULTURE SECTOR}

The application of flow meters [4] in cultivation and dams are increased within increase in the demand of irrigation, drinking water and power supply using hydraulic power stations. These water flow meters are tool for the cultivators. The case study from a farm filed with mango plantation was collected from the district Agriculture officer and based on the data the required para maters are evaluated. The agriculture if updated day to day with the reforms and agriculture policies in the country, with this the farming is implemented with the natural fertilizers and led to organic farming. Organic farming is a method of crop production that involves not to use pesticides, fertilizers, genetically modified organisms, antibiotics and growth hormones, but for the organic farming also required sufficient uniform flow of water.

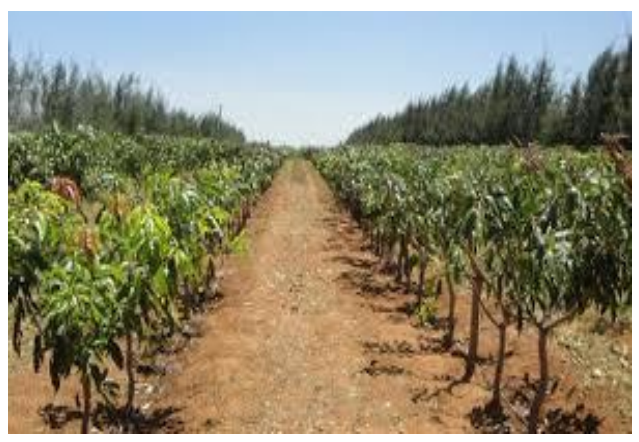

Figure.2. Mango Plantation 


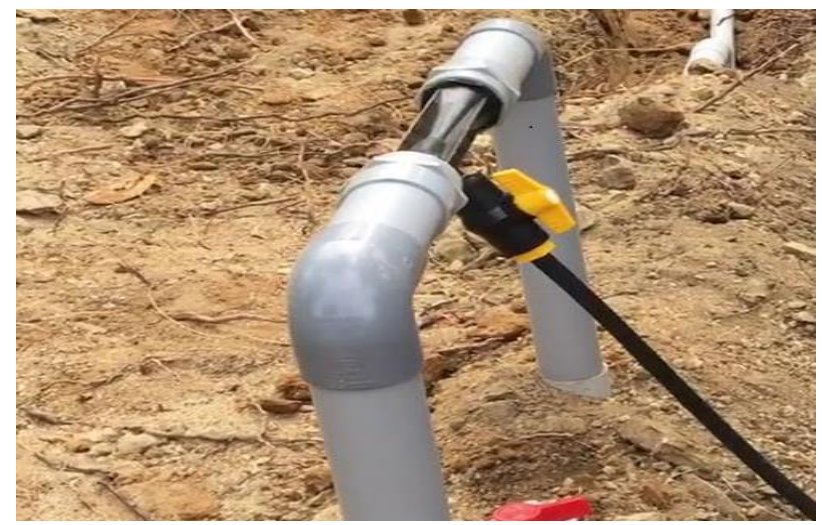

Figure.3. Pipe connected to submerged pump

\section{CALCULATION OF VENTURIMETER THROAT}

The mango plantation with 4 ACRES will have 2,700 Mango plants as Each Acre can have 675 Plants. For these plantation to the rich nutrients can be supplied in the form of fertilizer mixed with the water in the ratio of 1:4 quantity the ratio indicate for one part of fertilizer needed 4 parts of water. The fertilizers for mango plants are $\mathrm{N}, \mathrm{P}_{2} \mathrm{O}_{5}, \mathrm{~K}_{2} \mathrm{O}$ can be used based on the requirements, More amount of $\mathrm{K}_{2} \mathrm{Ois}$ supplied for the plants as per Agriculture principle $220 \mathrm{kgs}$ of $\mathrm{K}_{2} \mathrm{O}$ is supplied in year, on an average $7 \mathrm{~g} /$ tree is supplied.

No of Acres of land $\quad=6$

No of mango plants for 1 Acre $=675$

For 6 Acres Mango plants $=4050$ Plants

Fertilizer required

$$
\begin{aligned}
& =4050 \times 7 \mathrm{gm} \\
& =28350 \mathrm{gm} \\
& =28.35 \mathrm{Kgs}
\end{aligned}
$$

Fertilizer in liters

$$
=114 \text { liters }
$$

Time for fertilizer Empty $=203$ seconds

$\mathrm{QF}_{\mathrm{F}}$

$$
\begin{aligned}
& =\frac{114}{360}=0.316 \mathrm{lt} / \mathrm{sec} \\
& =0.316 \times 10^{-3} \mathrm{~m}^{3} / \mathrm{sec}
\end{aligned}
$$

Submersible pump of 6 H.P with discharge of $0.00227 \mathrm{~m}^{3} / \mathrm{sec}$ is choosen.

$$
\mathrm{QP}_{\mathrm{P}}
$$

$$
=0.00227 \mathrm{~m}^{3} / \mathrm{sec}
$$

Total Discharge required is obtained by adding the discharge of choosen pump and discharge of the fertilizer

$$
\begin{aligned}
\mathrm{Q}_{\text {Total }} & =\mathrm{Q}_{\mathrm{F}}+\mathrm{Q}_{\mathrm{P}} \\
& =0.00227+0.000316 \\
& =0.002586 \mathrm{~m}^{3} / \mathrm{sec}
\end{aligned}
$$

Consider
Diameter of the throat $\quad=\mathrm{d}_{2}$

Diameter of the pipe $\quad=0.04 \mathrm{~m}$

Area of the throat

$$
=\frac{\pi d_{2}^{2}}{4}
$$

Area of the pipe

$$
=\frac{\pi d_{1}^{2}}{4}=0.001256 \mathrm{~m}^{2}
$$

$$
\begin{aligned}
& \mathrm{g}=9.81 \mathrm{~m} / \mathrm{sec}^{2} \\
& \mathrm{Q}_{\text {the }}=A_{1} \times A_{2} \sqrt{2 g \delta h} \\
& \sqrt{A_{2}^{2}}-\sqrt{A_{1}^{2}}
\end{aligned}
$$

Coefficient of discharge $=\mathrm{Q}_{\text {act }} / \mathrm{Q}_{\text {the }}$

$\mathrm{C}_{\mathrm{d}}$ is the coefficient of discharge for venturimeter and its value is always less then 1 , the value varies from (0.93-0.98)

$\mathrm{H}=$ Height of fertilizer in drum +Atmospheric pressure head

$$
\begin{aligned}
& =0.56 \mathrm{~m}+10.3 \mathrm{~m} \\
& =10.86
\end{aligned}
$$

$$
\begin{aligned}
\mathrm{Q}_{\text {the }}= & A_{1} \times A_{2} \sqrt{2 g \delta h} \\
& \sqrt{A_{2}^{2}}-\sqrt{A_{1}^{2}} \\
\mathrm{Q}_{\text {the }} \quad= & 0.001256 \times A_{2} \times \sqrt{2 \times 9.81 \times 10.86} / \sqrt{A_{2}^{2}-A_{1}^{2}}
\end{aligned}
$$

Taking $\mathrm{Q}_{\text {the }}=0.002586 \mathrm{~m}^{3} / \mathrm{sec}$ on simplification

$$
\begin{aligned}
& \mathrm{A}_{2}=0.00017295 \\
& \mathrm{D}_{2}=0.0148 \mathrm{~m}
\end{aligned}
$$

The throat diameter can be taken as $0.0 .148 \mathrm{~m}$

Loss Coefficient

For $\mathrm{C}_{\mathrm{d}}=0.98$

Loss coefficient $\left(\mathrm{K}_{\mathrm{v}}\right),[7]$.

$$
K_{V}=\frac{2 g \times h_{L}}{V^{2}}
$$

$$
\begin{array}{ll}
\mathrm{V} & =\mathrm{Q} / \mathrm{A} \\
& =2.05 \mathrm{~m} / \mathrm{sec} \\
\mathrm{h}_{\mathrm{L}} & =\mathrm{H}\left(1-\mathrm{C}_{\mathrm{d}^{2}}\right) \quad=0.43 \\
\mathrm{~K}_{\mathrm{V}} & =2.007
\end{array}
$$




\section{RESULTS AND DISCUSSION}

TABLE.1: CALCULATED PARAMETERS OF VENTURIMETER

\begin{tabular}{|l|l|l|}
\hline S.NO & PARAMETER & VALUE \\
\hline 1. & Throat Diameter & $0.0148 \mathrm{~m}$ \\
\hline 2. & Discharge & $0.002586 \mathrm{~m}^{3} / \mathrm{sec}$ \\
\hline 3. & Loss coefficient & 2.007 \\
\hline
\end{tabular}

TABLE.2: DIAMETER FOR DIFFERENT NO OF PLANTS

\begin{tabular}{|l|l|l|l|}
\hline & $\begin{array}{l}\text { NO OF } \\
\text { PLANTS }\end{array}$ & HEAD & $\begin{array}{l}\text { THROAT } \\
\text { DIAMETER }\end{array}$ \\
\hline 1 & 4050 & 10.86 & $0.0148 \mathrm{~m}$ \\
\hline 2 & 2025 & 5.43 & $0.0074 \mathrm{~m}$ \\
\hline 3 & 675 & 1.81 & $0.0024 \mathrm{~m}$ \\
\hline
\end{tabular}

\section{CONCLUSION}

The design of venturimeter throat is calculated without considering minor and losses by taking the practical values from the agricultural filed of 6 Acres of mango plantation and the amount of fertilizer quantity may vary from crop to crop and depends on season and also on required nutrients to be supplied. The diameter of the throat is not constant for all crops and the diameter may vary by choosing the submerged pump discharge quantity also and by determining the throat diameter the uniform discharge quantity is maintained and reduces the wastage of the fertilizer and investment on these fertilizers can be saved, with the less effort of the farmers all the plantation can be get the required sufficient amount of fertilizers and water. The loss coefficient value is calculated to determine the loss in pipe flow From the results calculations when no of plants decreases the throat diameter and head is varied and the results explains that for less acres of land a minimum vale of diameter of throat can be calculated.

\section{REFERENCES}

1. J.Kumar, J. Singh, H. Kansal, G. S. Narula, P. Singh. CFD Analysis of Flow Through Venturi. International Journal of Research in Mechanical Engineering \& Technology. 4(2): 2014, 214-217.

2. Kumar P,San SM.CFD Study of the Effect of Venturi Convergent and Divergent Angles on Low Pressure Wet Gas Metering.J Appl Sci.2014; 14(22): 3036-45p

3. Arun $\mathrm{R}$ Prediction of discharge coefficient of Venturimeter at low Reynolds numbers by analytical and CFD Method International Journal of Engineering and Technical Research (IJETR) Volume-3, Issue-5, May 2015.
4. Tom grill \& Mark Niblack,-Flow Measurement with Long-Throated Flumes under Uncertain Submergencell, A journal of U.S. department of Irrigation, Vol. III, Page No.5660, may 2009.

5. Dr.R.W.Miller, First New Proven Venturimeter, National journal of Amity Flow Co. Ltd, Vol 1, Page No 5-9, 2001.

6. Bansal R. K.., - Venturimeter, A textbook of fluid Mechanics\&Hydraulic Machines, Laxmi Publications Ltd, Bangalore, Page No 265 to 267, 2008.

7. Rajput R.K., 一Differential Pressure Head, Textbook of Fluid Mechanics, S.Chand Publication New Delhi, Page No. 189 to 190, 2005. 